\title{
Analisis Optimalisasi Anggaran Penjualan dalam Peningkatan Kinerja Perusahaan
}

\author{
Amran Hotman Saragih \\ Sekolah Tinggi Akuntansi Dan Manajemen Indonesia \\ amran.saragih@yahoo.com
}

\author{
Asmawati \\ Sekolah Tinggi Akuntansi Dan Manajemen Indonesia \\ asmawatidamanik@gmail.com \\ Casria Sidabalok \\ Sekolah Tinggi Akuntansi Dan Manajemen Indonesia \\ casria123@gmail.com
}

\begin{abstract}
Abstrak
Operational budget is a budget to prepare corporate income, where operating budget consists of revenue and expenditure for the company itself mendaptkan a net profit corporation. So also in this study aims to provide an overview of the implementation of the budget as a tool of management control in PDAM Pematangsiantar. The company has established operating budget is quite relevant in accordance with the previous year's evaluation to benchmark maketh ato size for a specified budget. Where the income and expenses incurred in 2011 and 2012 looks a distinguish between the realization set budget. It is caused by the presence of certain programs that have not been fully terlakasna and other factors such as inflation and rising budgetary capacities and volumes that were previously budgeted smaller apparently greater realization. So this led to an increase in budget and affect the realization
\end{abstract}

Keywords Operating Budget, Evaluation, PDAM Pematangsiantar

\section{PENDAhuluan}

Kebutuhan akan air bersih masyarakat perkotaan terus meningkat, hal tersebut disebabkan jumlah penduduk yang terus bertambah dengan disertai semakin banyaknya lahan penyerapan air yang berubah fungsi menjadi daerah pemukiman dan gedung-gedung perbelanjaan. Hal tersebut juga terjadi di wilayah Pematangsiantar, sehingga untuk memenuhi kebutuhan air bersih yang layak untuk dikonsumsi dipasok sepenuhnya oleh Perusahaan Daerah Air Minum (PDAM) Pematangsiantar. PDAM merupakan kesatuan usaha (organisasi) milik pemerintahdaerah yang memberikan jasa pelayanan dan menyelenggarakan kemanfaatan umum di bidang air minum. Setiap organisasi terbentuk karena adanya keinginan semua pihak pendiri oraganisasi untuk mencapai suatu tujuan.Untuk mencapai tujuan tersebut, setiap oraganisasi mempunyai visi dan misi sebagai rancangan tindakan nyata dalam mencapai tujuan tersebut.akan tetapi, visi dan misi tersebut tidak akan berjalan dengan lancar tanpa adanya pengendalian dari manajemen sebagai 
pengontrol visi dan misi agar tetap berjalan sesuai dengan tujuan awal organisasi tersebut. Pengendalian yang dilakukan tidak hanya sebatas pengendalian pada tindakan (kegiatan) yang akan dilakukan saja melainkan pengendalian dalam bentuk financial (keuangan). Pengendalian kegiatan dijalankan dengan membuat rencana kegiatan, sedangkan pengendalian dalam bentuk keuangan dilakukan dengan membuat anggaran.

Anggaran adalah perencanaan keuangan untuk masa depan. Perencanaan dan pengendalian adalah dua hal yang tak terpisahkan. Perencanaan melihat ke masa depan, yaitu menentukan tindakantindakan apa yang harus dilakukan untuk merealisasikan tujuan tertentu. Pengendalian melihat ke belakang, yaitu menilai apa yang telah dihasilkan dan membandingkannya dengan rencana yang telah disusun. Anggaran perusahaan merupakan salah satu alat bantu bagi manajemen suatu perusahaan untuk merencanakan langkah- langkah financial penting serta menentukan kebijakan perusahaan di masa depan dalam periode tertentu. Hal tersebut sejalan dengan anggaran PDAM Pematangsiantar yang merupakan salah satu aspek penting di dalam merencanakan keputusan yang akan diambil oleh manajemen, sehingga apabila terjadi kekeliruan atau ketidaktepatan dalam merencanakan atau melaksanakan anggaran dapat berakibat buruk bagi perusahaan. Ketidaktepatan atau adanya selisih antara anggaran dan realisasinya juga terjadi di PDAM Pematangsiantar. Banyak sekali fenomena yang terlihat dalam kehidupan masyarakat akan kebutuhan air bersih dan itu semua terkendali oleh adanya PDAM Pematangsiantar. Akan tetapi, semua kebutuhan air bersih tidak selancar yang diinginkan masyarakat, karena adanya kebocoran pipa air yang ada di daerah daerah tertentu.Hal inimengakibatkan air yang dikonsumsi oleh masyarakat sekitar sering mengalami air mati bergilir.Sehingga perlu adanya penanggulanagan dan pengendalian dalam suatu perusahaan. Salah satu anggaran dilihat dari bidangnya adalah anggaran operasional.Pada anggaran tersebut terlihat pendapatan dan pengeluaran, sehingga dapat diketahui laba bersih perusahaan. Nilai laba bersih yang tinggi merupakan tujuan dari perusahaan, sehingga untuk mencapai tujuan tersebut diperlukan sebuah anggaran untuk merencanakan keuangan perusahaan. Biaya operasional merupakan biaya yang memiliki pengaruh besar di dalam mempengaruhi keberhasilan perusahaan di dalam mencapai tujuannya tanpa aktivitas operasional yang terarah, maka seluruh produk yang dihasilkan tidak akan memiliki manfaat apapun bagi perusahan.

\section{LANDASAN TEORI}

Pengertian Anggaran

Menurut Adisaputro dan Asri (2013) bussiness budget adalah suatu pendekatan yang formal dan sistematis daripada pelaksanaan tanggung jawab manajemen di dalam perencanaan, koordinasi dan pengawasan.

Tujuan Anggaran

Tujuan penyusunan anggaran menurut Nafarin (2014), diantaranya:

1.Untuk digunakan sebagai landasan yuridis formal dalam memilihsumber dan investasi dana.

2.Untuk mengadakan pembatasan jumlah dana yang dicari dandigunakan.

3.Untuk merinci jenis sumber dana yang dicari maupun jenis investasi

4.Untuk merasionalkan sumber dan investasi dana agar dapat mencapai hasil yang maksimal. 5.Untuk menyempurnakan rencana yang telah disusun, karena dengan anggaran lebih jelas dan nyata terlihat. 
6.Untuk menampung dan menganalisis serta memutuskan setiap usulanyang berkaitan dengan keuangan dapat dilaksanakan secara selaras dalam mencapai tujuan (laba).

Jadi anggaran penting untuk menyelaraskan (koordinasi) setiap bagian kegiatan, seperti bagian pemasaran, bagian umum, bagian produksi, dan bagian keuangan. Apabila salah satu bagian (departemen) saja tidak dapat melaksanakan tugas sesuai dengan yang direncanakan, maka bagian yang lain juga tidak dapat melaksanakan tugasnya sesuai rencana.

Anggaran sebagai fungsi Pengawasan

Anggaran merupakan alat pengendalian/pengawasan (controlling). Pengawasan berarti melakukan evaluasi (menilai) atas pelaksanaan pekerjaan, dengan cara:

a. Membandingkan realisasi dengan rencana anggaran.

b. Melakukan tindakan perbaikan apabila dipandang perlu (jika ada penyimpangan yang merugikan).

Keterbatasan Anggaran

Dalam menyusun anggaran terdapat

beberapa hal yang membatasi penyusunan anggaran.Menurut Adisaputro dan Asri (2003

: 53)keterbatasan anggaran tersebut diantaranya :

1. Karena anggaran disusun berdasarkan estimasi (potensi penjualan, kapasitas produksi dan lainlain) maka terlaksananya dengan baik kegiatan-kegiatan tergantung pada ketepatan estimasi tersebut.

2. Anggaran hanya merupakan rencana, dan rencana tersebut baru berhasil apabila dilaksanakan sungguh-sungguh.

3. Anggaran hanya merupakan suatu alat yang dipergunakan untuk membantu manajer dalam melaksanakan tugasnya, bukan menggantikannya.

Kondisi yang terjadi tidak selalu seratus persen sama dengan yang diramalkan sebelumnya, karena itu anggaran perlu memiliki sifat yang lowes.

Proses Pengendalian Anggaran

Menurut Mulyadi (2001 : 508) proses pengendalian anggaran dilaksanakan melalui tiga tahap utama, antara lain :

1. Tahap Penetapan Sasaran

Tujuan perusahaan kemudian dirinci lebih lanjut ke dalam sasaran (goal) dan dibebankan pencapaiannya kepada manajer tertentu dalam proses penyusunan anggarannya. Alokasi sumber daya dalam proses penyusunan anggaran perlu diukur dengan satuan moneter standar dengan menggunakan ukuran akuntansi. Informasi akuntansi manajemen berperan dalam tahap penetapan sasaran sebagai alat pengirim peran.

2. Tahap Implementasi

Setelah sasaran ditetapkan dan ditunjuk manajer yang bertanggung jawab atas pencapaian sasaran tersebut, serta dialokasikan sumber daya kepada manajer yang diberi peran dalam mencapai sasaran anggaran, fungsi anggaran dalamperusahaan kemudian mengkonsolidasikannya ke dalam suatu anggaran komprehensif yang formal untuk disahkan oleh direksi dan pemegang saham. Tahap implementasi anggaran dilaksanakan melalui dua kegiatan penting, yaitu:

a. Komunikasi anggaran

Manajer fungsi anggaran bertanggung jawab untuk mengkomunikasikan anggaran yang telah disahkan kepada para manajer jenjang menengah dan bawah. 
b. Kerjasama dan koordinasi

Untuk dapat menyelesaikan suatu tugas, orang harus mengetahui peran yang harus dimainkan oleh orang lain, baik dalam organisai formal maupun informal.

3. Tahap Pengendalian dan Evaluasi Kinerja Dalam tahap ini, kinerja sesungguhnya dibandingkan dengan standar yang tercantum dalam anggaran, untuk menunjukkan bidang masalah dalam organisasi dan menyarankan tindakan pembetulan yang memadai bagi kinerja yang berada di bawah standar.

\section{METODE PENELITIAN}

Penelitian ini merupakan suatu penelitian berbentuk study case yang biasanya dilakukan arahnya terfokus pada satu objek penelitian saja, seperti satu perusahaan yang diamati atau dijadikan penelitian. Selain itu, peneliti menggunakan penelitian dengan pendekatan kualitatif. Metode penelitian kualitatif dinamakan sebagai metode baru, karena populasinya belum lama, dinamakan metode postpostivistik karena berdasarkan pada filsafat postpositivisme. Metode ini disebut juga sebagai metode artistik karena proses penelitian lebih bersifat seni (kurang terpola), dan disebut sebagai metode interpretive karena data hasil penelitian lebih berkenaan dengan interpretasi terhadap data yang ditemukan di lapangan (Sugiyono, 2011:7) Dengan demikian, peneliti perlu memahami lebih mendalam mengenai permasalahan yang akan diteliti dengan terjun langsung ke dalamnya sehinga nantinya akan menemukan jawaban dari permasalahan yang ada serta dapat juga membentuk suatu gambaran dan teori baru. Metode pengumpulan data yang dilakukan dengan cara Observasi Partisipasif, Wawancara Semiterstruktur dan Dokumentasi (Sugiyono, 2011: 241). Penulis menggunakan beberapa teknik penelitian, yaitu:

Obeservasi partisipasi pasif, Observasi ini dilakukan dengan cara datang di tempat kegiatan subjek yang sedang diamati atau yang digunakan sebagai sumber data penelitian, tetapi tidak ikut terlibat dalam kegiatan tersebut. Dengan observasi ini, maka data yang diperoleh akan lebih lengkap(Sugiyono, 2011: 227).

Wawancara semiterstruktur. Wawancara semiterstruktur merupakan kategori in-dept interview, dimana dalam pelaksanaannya lebih bebas bila dibandingkan dengan wawancara terstruktur. Tujuan dari wawancara jenis ini adalah untuk menemukan permasalahan secara lebih terbuka, di mana fihak yang diajak wawancara dimintai pendapat, dan ide-idenya(Sugiyono, 2011:

233).Peneliti memilih model wawancara seperti ini karena peneliti ingin mendapatkan pendapatpendapat dan ide-ide dari objek yang diteliti mengenai perlakuanAnggaran Operasionalsebagai Alat Pengendalian Manajemen. Wawancara dilakukan pada kepala Sub Bagian Keuangan bagian anggaran operasional PDAM Pematangsiantar.

Dokumentasi. Dokumen adalah catatan peristiwa yang sudah berlalu. Dokumen bisa berbentuk tulisan, gambar, atau laporan. Dokumen berbentuk tulisan yang akan digunakan oleh peneliti pada penelitian ini adalah dokumen berupa laporan keuangan perusahaan tahun 2011-2012 di mana perusahaan telah mengganggarkan operasionalnya dan terealisasi dengan sesuai.

Rencana Pengujian Keabsahan Data. Jenis data yang digunakan adalah data primer dan data sekunder. Data primer diperoleh melalui wawancara langsung dengan pihak yang berperan dalam 
penyusunan anggaran perusahaan. Daftar pertanyaan wawancara dilihat pada Lampiran 1. Sedangkan data sekunder diperoleh dari perusahaan yang berupa dataanggaran dan realisasi tahun 2011 dan 2012, SOP PDAM Pematangsiantar, dan data tentang perusahaan. Selain itu data sekunder juga diperoleh dari buku-buku teks, karya ilmiah.

\section{Teknik Analisis Data}

Berikut ini rancangan analisis data yang akan dilakukan oleh peneliti, diantaranya sebagai berikut

\section{Pengumpulan data}

Pengumpulan data adalah proses pertama yang dilakukan pada penelitian ini. Pengumpulan data ini dilakukan dengan cara mengumpulkan semua data- data yang diperlukan untuk menunjang penelitian. Data tersebut diperoleh secara langsung dan tidak langsung melalui observasi, wawancara, dan dokumen yang ada di subjek penelitian yaitu PDAM Pematangsiantar. Data tersebut berupa jawaban dari hasil wawancara dan observasi pada bagian Anggaran Operasional. Penunjang dari hasil wawancara tersebut diperkuat lagi dengan adanya data asli berupa dokumen tertulis yang diberikan yaitu berupa laporan keuangan dan tahunan milik perusahaan. Pada saat pengumpulan data, tidak semua data yang dapat dikumpulkan baik dari hasil observasi, wawancara maupun dari dokumen yang ada, dipakai semuanya karena tidak semua data berkaitan dengan apa yang akan diteliti. Data tersebut harus dipilah-pilah lagi mana saja dari data tersebut yang nantinya akan menunjang penelitian. Oleh karena itu, pengumpulan data harus tetap mengacu pada rumusan masalah penelitian yang ada agar data yang dikumpulkan tidak melenceng terlalu jauh dari apa yang diperlukan seharusnya.

\section{Observasi Pengamatan}

Observasi pengamatan dilakukan langsung pada lokasi yaitu kantor PDAM Pematangsiantar yang dimana pengumpulan data dapat diperoleh oleh pihak pihak yang bersangkutan seperti bagian Keuangan terutama anggaran operasional dan kepegawaian.

3. Wawancara

Wawancara dilakukan secara langsung dengan pihak pihak yang bersangkutan dimana wawancara tersebut berkiatan dengan pertanyaan- pertanyaan yang menyangkut Anggaran operasioanl dan profil perusahaan PDAM Pematangsiantar.

4. Analisis anggaran operasional

Analisis yang dilakukan berupa analisis mendalam pada data yang sudah dikumpulkan yang berasal dari jawaban- jawaban hasil wawancara dan observasi serta data berupa angka-angka yang berasal dari laporan keuangan. Analisis tersebut dilakukan dengan cara menelaah dan mencocokkan anggaran operasional yang digunakan oleh perusahaan dengan permasalahan, standart akuntansi yang berlaku umum di Indonesia dalam Pernyataan Standart Akuntansi Keuangan (PSAK) serta asumsi yang ada mengenai anggaran operasional yang diasumsikan pada penelitian ini. Analisis yang digunakan adalah analisis deskriptif- kualitatif yang merupakan suatu teknik yang menggambarkan dan menginterpretasikan arti data-data yang telah terkumpul dengan memberikan perhatian dan merekam sebanyak mungkin pada aspek situasi yang diteliti pada saat itu, sehingga memperoleh gambaran secara umum dan menyeluruh tentang keadaan sebenarnya yang bertujuan untuk membuat deskripsi, gambaran atau lukisan secara sistematis, faktual dan akurat mengenai fakta-fakta, sifat-sifat serta hubungan antar fenomena yang diselidiki. Analisis 
ini yang nantinya akan membantu peneliti untuk menjawab permasalahan yang ada pada rumusan masalah yang ada pada penelitian.

5. Analisis Varians

Analisis Varians mencakup analisis matematis dari dua perangkat data untuk mendapatkan pendalaman penyebab terjadinya suatu penyimpangan/varians. Salah satu jumlah diperlakukan sebagai dasar, standar, atau titik pedoman. Analisis Varians mempunyai aplikasi yang luas dalam pelaporan keuangan.

Pada masing-masing situasi ini, analisis ini, analisis varians melibatkan pendekatan analisis yang sama. Perhitungan juga sama pentingnya. Satu- satunya perbedaan adalah dalam data yang dianalisis

Menurut Nafarin (2004 :230) Model tiga selisih :

Selisih Pengeluaran $=$ BOP sesungguhnya $-(\mathrm{BOP}$ variabel yang dianggarkan pada jam kerja sesungguhnya).

Selisih kapasitas $=($ kapasitas normal - kapasitas sesungguhnya $) \mathrm{x}$ tariff BOP tetap. Kapasitas normal > Kapasitas sesungguhnya, selisih fovarable

Kapasitas normal < $\quad$ Kapasitas sesungguhnya, selisih unfovarable

Selisih efisiensi $=($ jam kerja standar - jam kerjq sesungguhn ya) $\mathrm{x}$ tariff BOP total.

6. Evaluasi Anggaran

Evaluasi anggaran pada dasarnya membandingkan antara anggaran dengan pelaksanaan sehingga ditentukan penyimpangan yang terjadi. Penyimpangan ini akan digunakan sebagai dasar untuk mengukur efisiensi serta penilaian prestasi. Anggaran yang digunakan dalam mengevaluasi prestasi cenderung mempengaruhi perilaku dan prestasi para pelakunya.

\section{HASIL DAN PEMBAHASAN}

Analisis Varians Terhadap Anggaran Operasional dan Realisasinya

Pada tahun 2011, perusahaan berhasil mencapai pendapatan usaha senilai Rp.131.076.095.083 yaitu sebanyak 102\% dari yang telah dianggarkan perusahaan senilai Rp.128.041.991.076. Selisih antara anggaran dan realisasi pendapatan di tahun ini adalah senilai Rp.3.034.104.007 atau sebesar $2 \%$ dari pendapatan yang telah dianggarkan. Pendapatan usaha tersebut terdiri dari empat komponen pendapatan, yaitu :

1. Pendapatan penjualan air

2. Pendapatan non air

3. Pendapatan lain-lain

4. Keuntungan luar biasa

Dari keempat komponen pendapatan tersebut, jenis pendapatan yang paling banyak berkontribusi dalam peningkatan realisasi pendapatan usaha adalah pendapatan lain-lain dengan prosentase sebanyak 338\% dari yang telah dianggarkan, yaitu dengan jumlah realisasi sebesar Rp.2.624.789.533 dan anggaran senilai Rp.777.351.028. Selisih atau varians yang terjadi antara pendapatan lain- lain yang telah dianggarkan dengan realisasinya adalah sebesar $238 \%$ dari yang telah dianggarkan. Pendapatan lain-lain tersebut berasal dari kelebihan perhitungan iuran pensiun.Pada tahun ini, bisa dikatakan perusahaan telah berhasil dalam merealisasikan pendapatan usahanya yang telah dianggarkan sebelumnya.Akan tetapi, di tahun ini perusahaan tidak dapat meminimalisir biaya yang dikeluarkan. Pada tahun ini, total biaya yang direalisasikan oleh 
perusahaan adalah senilai Rp.115.694.742.549 atau sebesar 102\% dari anggarannya yaitu senilai Rp.113.175.122.728, sedangkan selisih atau varians yang terjadi adalah sebesar $2 \%$ dari total biaya yang telah dianggarkan. Komponen biaya yang paling tinggi realisasinya adalah biaya transmisi dan distribusi yaitu senilai Rp.27.411.635.711 yaitu sebesar $106 \%$ dari yang telah dianggarkan senilai Rp.25.776.338.955, dan terjadi varians atau selisih sebesar 6\% dari yang telah dianggarkan. Besarnya biaya transmisi dan distribusi ini disebabkan tingginya biaya penyusutan instalasi transmisi dan distribusi. Laba yang dapat dicapai di tahun ini adalah sebesar 103\% yaitu senilai Rp.11.536.014.401 lebih besar dari anggarannya yaitu senilai Rp.11.150.151.261 dan dengan varians atau selisih yang terjadi sebesar 3\%.

Berbeda dengan tahun 2011, pada tahun 2012 perusahaan tidak dapat mencapai anggaran yang telah dibuat oleh perusahaan. Pada tahun 2012, perusahaan hanya dapat mencapai $99 \%$ yaitu senilai Rp.135.111.721.156 dari anggarannya yaitu senilai Rp.136.318.086.578 atau bisa dikatakan dengan varians sebesar $1 \%$ dari yang telah dianggarkan oleh perusahaan. Dari pendapatan yang direalisasikan tersebut, jumlah pendapatan yang paling tinggi adalah pendapatan lain-lain yaitu sebesar 106\% atau senilai Rp.2.320.465.047 dari anggarannya Rp.2.194.661.006 dan terjadi varians sebesar

6\%. Pendapatan lain-lain tersebut adalah rupa- rupa pendapatan lainnya. Biaya yang direalisasikan perusahaan di tahun 2012 senilai Rp.122.400.691.402 sebanyak 98\% dari yang dianggarkan yaitu senilai Rp.125.099.622.683 dengan varians sebesar 2\%. sama halnya di tahun 2011, komponen biaya tertinggi adalah biaya transmisi dan distribusi berupa biaya pemeliharaan pipa yaitu senilai Rp.3.587.115.213 atau sebanyak 105\% dari anggarannya yaitu senilai Rp.3.426.222.848 dan dengan varians sebesar 5\%. Laba perusahaan yang dapat direalisasikan di tahun ini adalah sebesar 113\% yaitu senilai Rp.9.533.272.316 dari anggarannya yaitu senilai Rp.8.413.847.921 dengan varians sebesar 13\% dari yang telah dianggarkan oleh perusahaan. Pendapatan usaha yang direalisasikan di tahun 2012 yaitu senilai Rp.135.111.721.156 lebih besar 103\% dari yang direalisasikan di tahun 2011 yaitu senilai Rp.131.076.095.083 dengan varians yang terjadi sebesar 3\% dari anggarannya. Sama halnya pendapatan usaha, untuk biaya yang direalisasikan tahun 2012 juga lebih besar sebanyak 106\% atau senilai Rp.122.400.691.402 lebih banyak dari tahun 2011 senilai Rp.115.694.742.549 dengan total varians sebesar 6\%. Berbeda dengan pendapatan dan biaya, untuk laba setelah pajak yang direalisasikan lebih besar di tahun 2011 sebesar 121\% yaitu senilai Rp.11.536.014.401 daripada di tahun 2012 yaitu senilai Rp9.533.272.316 dan dengan varians sebesar $21 \%$ dari yang telah dianggarkan oleh perusahaan.

PDAM Pematangsiantar memiliki empat program yang setiap tahunnya direncanakan dan dilaksanakan. Empat program tersebut terdiri dari :

1. Program peningkatan pendapatan

2. Program peningkatan laba perusahaan

3. Program peningkatan kepuasan pelanggan

4. Program peningkatan profesionalisme sumber daya manusia

Program-program tersebut secara rutin diadakan oleh perusahaan untuk setiap tahunnya. Hanya saja, untuk kegiatan yang dilakukan, mungkin ada sedikit perbedaan setiap tahunnya untuk mencapai tujuan dari adanya program-program tersebut.

Pada tahun 2011 program pertama yaitu program peningkatan pendapatan dilaksanakan dengan beberapa kegiatan diantaranya adalah sebagai berikut : 
1. Pembenahan sistim jaringan perpipaan

2. Mengoptimalkan fungsi tim tingkat kehilangan air

3. Penataan pelanggan sesuai dengan sub zoning

4. Pemasangan meter induk pembatas wilayah dan pemasangan meter induk input sistem dan output

5. Penggantian meter air pelanggan sebanyak 7872 unit

6. Pendampingan pembaca meter

7. Pembentukan tim khusus untuk penagihan

8. Penindakan tegas bagi pelanggan yang terlambat membayar

Pelaksanaan kegiatan untuk melaksanakan program pertama ini membuat perusahaan harus mengeluarkan biaya.Berikut ini tabel yang menggambarkan anggaran dan realisasi pendapatan dan biaya selama tahun 2011. Pelaksanaan kegiatan dalam program pertama ini, perusahaan mengeluarkan biaya dalam kelompokbiaya administrasi dan umum serta biaya transmisi dan distribusi.Berdasarkan tabel di atas, ke dua biaya tersebut pada tahun 2011 masing- masing dianggarkan senilai Rp.31.538.606.873 dan Rp.25.776.338.955. Sedangkan realisasinya masingmasing senilai Rp.30.461.704.406 dan Rp.27.411.635.711. Pada biaya umum dan administrasi anggaran lebih besar daripada realisasinya atau bisa dikatakan terjadi varians sebesar $3 \%$. Hal ini dikarenakan perusahaan dapat melakukan penghematan atas biaya tersebut. Sedangkan untuk biaya transmisi dan distribusi, jumlah realisasinya lebih besar dari yang dianggarkan yaitu dengan varians sebesar 6\%. Hal ini terjadi karena adanya biaya pembenahan sistem jaringan perpipaan dan penggantian meter air pelanggan sebanya 7872 unit.

Pada program yang ke dua yaitu program peningkatan laba perusahaan, kegiatan yang direncanakan adalah sebagai berikut :

1. Penggunaan kertas pembayaran rekening air

2. Penghematan listrik dan pengguna air

3. Pemakaian BBM (Bahan Bakar Minyak) dan Solar secara tepat

Pencapaian program ini dilakukan perusahaan dengan melaksanakan kegiatan penghematan atau efisiensi biaya kantor. Akan tetapi, berdasarkan tabel 2 di atas, diketahui bahwa perusahaan masih belum dapat melakukan penghematan kantor yang dibuktikan dari realisasi biaya kantor senilai Rp.4.062.099.624 yang lebih besar dari anggarannya Rp.3.205.029.072 sehingga terjadi varians sebesar $27 \%$. Besarnya biaya ini tidak membuat perusahaan gagal dalam mencapai dan melaksanakan program ke dua ini. Program ini tetap dapat terlaksana dengan baik yang dibuktikan dengan jumlah laba perusahaan pada realisasi senilai Rp.11.536.014.401 yang jumlahnya lebih besar dari yang dianggarkan perusahaan senilai Rp.11.150.151.261 dengan varians sebesar 3\% sehingga, di tahun 2011 ini dapat dikatakan bahwa program ke dua perusahaan dapat terlaksana.

Pada program yang ke tiga yaitu program peningkatan kepuasan pelanggan, terdiri dari :

1. Training pelayanan prima bagi pegawai yang berhubungan langsung dengan pelanggan

2. Perbaikan fasilitas pelayanan

3. Program hibah air minum dari Australia

4. Perbuatan filter karbon aktif di IPA Siwalanpanji

5. Pengadaan pompa distribusi cadangan di IPA Krian dan IPA Siwalanpanji 
6. Menerapkan pengawasan melekat dan pendekatan manusiawi dengan operator IPA dan boster maupun kasie IPA

7. Pelatihan kepada para operator mengenai proses IPA, pompa dengan ampere, tekanan, bukan valve, baik pengetahuan maupun trouble shafting

8. Meningkatkan dan memelihara sarana dan prasarana IPA secara rutin

9. Rehabilitasi pipa Umbulan

10. Tambah daya PLN diinstalasi pengelolaan air

Perusahaan memasukkan biaya yang digunakan untuk pelaksanaan kegiatan dalam program tersebut pada biaya hubungan pelanggan yang masuk dalam biaya umum dan administrasi. Perusahaan pada awalnya menganggarkan biaya tersebut senilai Rp.1.441.132.592, dan pada realisasinya senilai Rp.1.617.310.554. Jumlah realisasi dana yang terserap sekitar 112\% dari junlah yang telah dianggarkan, dengan varians sebesar $12 \%$. Jumlah realisasi yang lebih besar daripada anggarannya ini menunjukkan bahwa perusahaan telah melaksanakan kegiatan yang ada pada program tersebut dan memasukkan biayanya pada komponen biaya umum dan administrasi, khususnya terkait dengan biaya hubungan langganan, karena pada program ke tiga ini perusahaan banyak melakukan kegiatan yang berkaitan dengan pelanggan.

Pada program terakhir perusahaan yaitu program peningkatan profesionalisme sumber daya manusia, perushaan merencanakan beberapa kegiatan diantaranya adalah :

1. Melakukan kerjasama dengan perguruan tinggi ataupun dengan supplier untuk melakukan pelatihan-pelatihan

2. Mengirimkan pegawai atau staff mengikuti undangan-undangan workshop, seminar dan pelatihan

3. Pelaksanaan dan mengintensifkan forum-forum diskusi pegawai

4. Tersedianya sarana dan prasarana bagi pegawai demi kelancaran proses pekerjaan.

Pelaksanaan program ini dilakukan perusahaan dengan melaksanakan kegiatan yang telah direncanakan. Pelaksanaan kegiatan tersebut menimbulkan biaya pegawai yang termasuk dalam komponen biaya umum dan administrasi. Pada tahun 2011, perusahaan menganggarkan biaya pegawai senilai Rp.18.993.825.156 dan realisasinya senilai Rp.18.704.795.412 sehingga terjadi varians sebesar $2 \%$. jumlah yang dianggarkan perusahaan lebih besar dari jumlah realisasinya. Hal ini dapat menekan jumlah biaya yang dikeluarkan sehingga dapat meningkatkan jumlah pendapatan dan laba perusahaan. Program ini telah dilaksanakan oleh perusahaan dengan mengikutkan pegawai perusahaan dalam seminar-seminar dan pelatihan baik internal maupun eksternal perusahaan.

Secara keseluruhan, dari total pendapatan dan total biaya yang terjadi di tahun 2011 terjadi varians sebesar $2 \%$ dari total pendapatan dan total biaya yang telah dianggarkan sebelumnya oleh perusahaan. Berdasarkan varians yang ada yang hanya menunjukkan angka $2 \%$ ini, dapat dikatakan bahwa di tahun 2011 perusahaan sudah cukup efektif dalam membuat anggaran. Sehingga pada tahun ini varians yang terjadi cukup kecil.

Pada tahun 2012 pelaksanaan kegiatan untuk mencapai program tersebut perusahaan menganggarkan pendapatan dari penjualan airsenilai Rp.123.573.467.446 sedangkan yang dapat direalisasikan senilai Rp.128.176.867.605. Varians yang terjadi adalah sebesar 4\%.Hal ini 
menunjukkan bahwa program tahunan PDAM Pematangsiantar yang pertama yaitu peningkatan pendapatan dapat tercapai pada tahun 2012 ini. Peningkatan pendapatan tersebut juga ditunjang dengan penurunan biaya keseluruhan pada tahun 2012. Total keseluruhan biaya yang telah dianggarkan perusahaan senilai Rp.125.099.622.683, sedangkan realisasinya perusahaan dapat menghemat biaya sebanyak Rp2.698.931.281, dengan varians yang terjadi sebesar 2\%. Sehingga pada tahun 2012, biaya yang terjadi adalah senilai Rp.122.400.691.402. Pada program peningkatan pendapatan yang telah diprogramkan, terdapat beberapa kegiatan yang menunjang untuk merealisasikan peningkatan pendapatan tersebut. Pelaksanaan kegiatan tersebut juga membuat perusahaan mengeluarkan biaya. Berikut ini adalah biaya yang dikeluarkan beserta kegiatan yang diprogramkan oleh perusahaan untuk meningkatkan pendapatan :

\section{Biaya Transmisi dan Distribusi}

a. Rehab jembatan pipa distribusi

b. Pembenahan sistem jaringan perpipaan

c. Mengoptimalkan fungsi tim tingkat kehilangan air

d. Penataan pelanggan sesuai dengan sub zoning

e. Pemasangan meter induk pembatasan wilayah dan pemasangan meter induk input sistem dan output sistem

Untuk menunjang program peningkatan pendapatan, perusahaan telah membuat lima rencana kegiatan dengan anggaran biaya transmisi dan distribusi senilai Rp.27.598.156.436 sedangkan realisasinya perusahaan mengeluarkan dana untuk biaya ini senilai Rp.28.902.831.452 dengan varians sebesar $5 \%$.

\section{Biaya Umum dan Administrasi}

a. Pendampingan pembaca meter

b. Pembentukan tim khusus untuk penagihan

c. Penindakan tegas bagi pelanggan yang terlambat membayar

Untuk biaya umum dan administrasi, perusahaan menganggarkan senilai Rp.31.298.720.752 dengan realisasi senilai Rp.32.365.086.950 dan varians sebesar 3\%.

Meskipun dua komponen biaya ini jumlah realisasinya lebih besar daripada anggarannya, kenyataannya perusahaan tetap berhasil dalam merealisasikan programnya yang pertama yaitu meningkatkan pendapatannya. Hal ini bisa terjadi karena, disisi lain perusahaan dapat menghemat biaya pengelolaan air senilai Rp.3.452.723.483 atau dengan varians sebesar 6\% dari anggaran senilai Rp.62.702.199.926, realisasinya hanya senilai Rp.59.249.476.443. Peningkatan pendapatan di tahun 2012 ini menunjukkan bahwa program ini dapat terlaksana dengan baik di tahun 2012. Selain meningkatkan pendapatan, perusahaan masih memiliki beberapa program pada tahun 2012. Program kedua perusahaan di tahun 2012, adalah peningkatan laba perusahaan. Program ini masih merujuk atau berkaitan dengan program perusahaan yang pertama yaitu peningkatan pendapatan. Perusahaan mengharapkan ketika pendapatan perusahaan meningkat, maka secara otomatis laba perusahaan juga akan meningkat. Akan tetapi, peningkatan pendapatan tidak selalu berdampak pada peningkatan laba perusahaan jika tidak diimbangi dengan pelaksanaan penghematan biaya yang dilakukan oleh perushaan. Perbedaaan yang terlihat dari program peningkatan pendapatan dan peningkatan laba ini terlihat dari segi biaya yang dikeluarkan oleh perusahaan. Jika pada 
program yang pertama yaitu program peningkatan pendapatan, perusahaan lebih banyak mengeluarkan biaya yang terkait dengan pelaksanaan dan penunjangan proses produksi dan penjualan yang dilakukan oleh perusahaan. Akan tetapi, untuk program yang kedua yaitu program peningkatan laba, hal ini lebih dikaitkan pada biaya kantor yang termasuk dalam biaya umum dan administrasi perusahaan. Berikut ini beberapa kegiatan yang dilakukan oleh perusahaan untuk melaksanakan program peningkatan laba perusahaan :
a. Penggunaan kertas pembayaran rekening air
b. Pemasangan inverter di IPA Tawangsari, IPA Kedunguling, IPA Krian, IPA Siwalanpanji, Boster Tambak Oso
c. Penghematan listrik dan penggunaan air
d. Pemakaian BBM (Bahan Bakar Minyak) dan solar secara tepat

Pelaksanaan ke empat kegiatan tersebut diharapkan nantinya akan mengurangi jumlah biaya yang dikeluarkan oleh perusahaan sehingga perusahaan dapat meningkatkan labanya sesuai dengan program ke dua perusahaan yaitu peningkatan laba perusahaan. Akan tetapi, pada tahun 2012, biaya umum dan administrasi perusahaan yang telah dianggarkan tidak dapat terlaksana, dalam artian realisasinya lebih besar daripada anggarannya senilai Rp.1.066.366.198 atau bisa dikatakan dengan varians sebesar 3\%. Hal ini terjadi karena untuk pencapaian program yang ke dua yaitu peningkatan laba perusahaan, perusahaan harus melaksanakan efisiensi biaya diantaranya dengan melaksanakan kegiatan yang telah direncakan.

\section{KESIMPULAN}

Tujuan dari penelitian ini adalah untuk memberikan gambaran mengenai penerapan anggaran sebagai alat Pengendalian Manajemen di PDAM Pematangsiantar.Berdasarkan hasil pengamatan dan penelitian yang telah dilakukan dengan metode kualitatif, dengan responden Kepala Keuangan dan Bagian Anggaran dan objek penelitiannya adalah PDAM Pematangsiantar, hasilnya menunjukkan bahwa pada PDAM Pematangsiantar, setiap anggaran yang dibuat tidak bisa 100\% sama ketika realisasinya. Pada tahun 2011, dana yang terserap untuk biaya operasional adalah senilai $102 \%$. Hal ini menunjukkan bahwa anggaran yang dibuat oleh perusahaan bisa dikatakan tidak efektif sebab biaya yang direalisasikan lebih besar dari yang telah dianggarkan.Pada tahun 2012, yang terserap senilai 98\% dari yang telah dianggarkan.Berbeda dengan tahun 2011, pada tahun 2012 ini perusahaan dapat menghemat biaya yang dikeluarkan sehingga perusahaan di tahun ini bisa lebih efektif karena biaya yang direalisasikan lebih kecil dari yang dianggarkan.

Hal ini disebabkan oleh beberapa faktor, diantaranya adalah tingkat inflasi dan ketidak mampuan pihak manajemen untuk memprediksi beban-beban tidak terduga. Akan tetapi, pada anggaran dan realisasi operasional tahun 2011 dan 2012 PDAM Pematangsiantar, selama dua tahun berturut-turut tersebut PDAM cukup baik dalam membuat anggarannya karena antara anggaran dan realisasi yang terjadi, tidak cukup besar varians yang terjadi. Hal ini menunjukkan adanya pengendalian manajemen yang baik karena dapat mengelola anggaran sehingga realisasinya tidak jauh dari anggaran yang telah dibuat.

Keterbatasan penelitian ini adalah Perusahaan tidak bisa memberikan rincian anggaran dan realisasi sesuai dengan kegiatan yang dilaksanakan dalam setiap program. 
Penulis menyadari bahwa penelitian yang telah dilakukan belumlah sempurna dan masih memiliki keterbatasan-keterbatasan. Oleh karena itu, berikut ini akan diberikan saran-saran yang mungkin berguna untuk kepentingan bersama. Saran yang dapat diberikan oleh penulis berkaitan dengan penelitian ini adalah :

1. Sebaiknya perusahaan perlu memasukkan faktor-faktor eksternal (inflasi) dalam pembuatan anggaran, sehingga varians yang terjadi antara anggaran dan realisasi dapat lebih diminimalisir lagi.

2. Untuk peneliti selanjutnya yang akan melakukan penelitian dengan topik yang sama, sebaiknya tidak hanya melakukan penelitian di satu perusahaan saja melainkan di beberapa perusahaan, minimal dua perusahaan, sehingga bisa dilakukan perbandingan dan pengamatan lebih mendalam sehingga hasilnya lebih valid dan general lagi.

\section{REFERENSI}

Adisaputro, Gunawan dan Asri, marwan. 2003. Penganggaran Perusahaan. Jakarta, Penerbit Salemba Empat.

Alim, Nizarul. 2008. "Efektivitas Perpaduan Komponen Anggaran dalamProsedur

Anggaran: Pengujian Kontinjensi Matching” Jurnal Akuntansi Dan Manajemen Vol. 10, No. 2, November 2008

Arifin, Johan. 2007. “ Pengaruh Karakteristik Gaya Penyusunan Anggaran Terhadap Efisensi Biaya “. Kajian Bisnis dan Manajemen Vol.9, No.1 Hal 23-25.

Delta Tirta. 2011.” Rencana Kerja Dan Anggaran”, Edisi Revisi 2011,Pematangsiantar.

Delta Tirta. 2012.” Rencana Kerja Dan Anggaran”, Edisi Revisi 2012,Pematangsiantar.

Nafarin, M. 2004. "Penganggaran Perusahaan", Edisi RevisiJakarta, Penerbit Salemba Empat.

Nafarin, M, 2009, Penganggaran Perusahaan, Edisi Tiga, Jakarta,Penerbit Salemba Empat.

Mulyadi. 2001. "Akuntansi Manajemen" : Konsep, Manfaat dan Rekayasa. Jakarta Salemba Empat..

Sugiyono, 2011. Metode Penelitian Kuantitatif, Kualitatif, dan R\&D. Alfabeta. Bandun 